\title{
PATTERN RECOGNITION: DESCRIPTION OF MODES OF TEACHING BOYS AGED 7 THROWING A SMALL BALL AT A VERTICAL TARGET
}

\author{
Ivashchenko O.V. ${ }^{1}$, Nosko M.O. ${ }^{2}$, Nosko Yu.M. ${ }^{3}$, Chernenko S.O. ${ }^{4}$ \\ ${ }^{1}$ H.S. Skovoroda Kharkiv National Pedagogical University \\ 2,3Taras Shevchenko National University of "Chernihiv Collegium" \\ ${ }^{4}$ Donbass State Machine-building Academy
}

Corresponding Author: Ivashchenko O.V., e-mail: olga@tmfv.com.ua

Accepted for Publication: September 20, 2019

Published: September 25, 2019

DOI:10.17309/tmfv.2019.3.04

\begin{abstract}
The study purpose was to determine the possibility of using pattern recognition methods to study the impact of physical exercises modes on teaching primary school children throwing a small ball at a vertical target.

Materials and methods. The study participants were boys aged 7 years $(n=48)$. The paper relied on analysis and generalization of data of scientific and methodological literature, general scientific methods of theoretical level, such as analogy, analysis, synthesis, abstraction, induction, as well as general scientific methods of empirical level: observation, testing, experiment.

Results. The effectiveness of teaching boys aged 7 "throwing a ball at a vertical target" is positively influenced by 6-12 sets, 3 repetitions per set, rest interval of 60-180 seconds. The focus in choosing a teaching mode is on the number of repetitions per set.

Conclusions. A full factorial experiment method makes it possible to mathematically describe the process in some local area of the factorial space and to verify the regression model. Regression equations provide an opportunity to select the modes of performing for each exercise being studied. Discriminant analysis has made it possible to determine the modes of physical exercises in the process of motor skills development; to answer the question as to how significantly the modes of training differ by the effectiveness of motor skills development; what motor tasks most substantially influence the differentiation of classes; what class the object belongs to based on the values of discriminant variables. To select the most rational mode of performing exercises in the process of motor skills development in boys aged 7, the first and second discriminant functions can be used, with a focus on the most informative variables.

Keywords: teaching, boys aged 7, factorial experiment, discriminant analysis.
\end{abstract}

\section{Introduction}

The objective of schoolchildren's physical education is to teach them motor actions and develop their motor abilities (Vaskov, 2016; Arziutov, Iermakov, Bartik, Nosko, \& Cynarski, 2016; Khudolii, Ivashchenko, \& Chernenko, 2015). The problem of planning the learning process and motor abilities development in schoolchildren is relevant for both Ukraine (Krucevich, \& Bezverkhnia, 2010; Ivashchenko, Khudolii, Yermakova, Pilewska, Muszkieta, \& Stankiewicz, 2015; Ivashchenko, Yermakova, Cieślicka, \& Śukowska, 2015; Khudolii, Iermakov, \& Prusik, 2015) and European

(c) Ivashchenko O.V., Nosko M.O., Nosko Yu.M., Chernenko S.O., 2019. countries (Ekberg, 2016; Lang, Feldmeth, Brand, Holsboer-Trachsler, Pühse, \& Gerber, 2017).

The effectiveness of schoolchildren's physical education is influenced by: the system of pedagogical control of the learning process and motor abilities development based on multidimensional statistics (Ivashchenko, 2016, 2017; Ivashchenko, \& Cieślicka, 2017); methodological approaches to streamlining the programs of teaching physical exercises (Ivashchenko, 2001; Miroshnychenko, 2007; Khudolii, 2008a, 2008b); taking into account the patterns of motor function development (Nosko, 2001; Nosko, Kryvenko, \& Manievych, 2001; Nosko, \& Sumak, 2000) and the body reaction to different modes of alternating physical exercises with rest intervals in the process of building motor skills and developing motor abilities in children and adolescents 
(Khudolii, \& Iermakov, 2011; Khudolii, Ivashchenko, Iermakov, \& Rumba, 2016).

The learning process is approached from the following perspectives:

- organization: it is suggested that the process of physical education in schools be planned by periods each having its goal (Krucevich, Trachuk, Napadij, 2016; Ekberg, 2016); educational process planning based on learning models and motor abilities development (Ivashchenko, 2016);

- motivation for motor activity: learning success positively influences a motivation for motor activity, the higher the level of proficiency in exercises performance, the wider the range of motor activity (Darnis, \& Lafont, 2015; Xu, \& Ke, 2014);

- connection between learning outcomes and motor activity: experimental data show that learning success leads to an increase in motor activity (Al-Ravashdeh Abdel Baset, Kozina, Bazilyuk, \& Ilnickaya, 2015; Lang et al., 2017);

- integration of cognitive and motor learning (Chatzipanteli, Digelidis, Karatzoglidis, \& Dean, 2016; Altunsoz, \& Goodway, 2016; Koh, Ong, \& Camiré, 2016);

- influence of motor preparedness on the effectiveness of building motor skills (Ivashchenko, 2017; Khudolii et al., 2016),

- influence of physical activity on the effectiveness of teaching schoolchildren motor actions (Ivashchenko, Kapkan, 2015; Kapkan, 2015).

Studies found out that the level of schoolchildren's motor preparedness is influenced by the correlation between learning processes and motor abilities development. (Ivashchenko, 2016). The development of motor abilities is effective provided that they form part of acquired motor skills (Khudolii, Ivashchenko, \& Chernenko, 2015). It was found that the effectiveness of learning improves when using the method of algorithmic instructions (Khudolii, 2008a, 2008b; Ivashchenko, 2001) and taking into account the modes of alternating exercises with rest (Khudolii, \& Ivashchenko, 2013; Ivashchenko, 2016, 2017).

One of the methods for studying the peculiarities of motor skills development in children and adolescents is modeling. Modeling is an effective method to obtain new information on the possibility of current and final control through testing children's and adolescents' motor preparedness (Khudolii, \& Ivashchenko, 2013, 2014; Lopatiev, Ivashchenko, Khudolii, Pjanylo, Chernenko, \& Yermakova, 2017; Vlasov, Demichkovskyy, Ivashchenko, Lopatiev, Pitin, Pjanylo, \& Khudolii, 2016). One of the statistical modeling methods is discriminant analysis, the data of scientific literature point to its effectiveness for the classification of children's and adolescents' functional and motor preparedness (Khudolii, \& Ivashchenko, 2014; Milić, Milavić, \& Grgantov, 2011; Ivashchenko et al., 2015; Khudolii et al., 2015). A full factorial experiment method makes it possible to mathematically describe the process in some local area of the factorial space and to verify the regression model. Regression equations provide an opportunity to select the modes of performing for each exercise being studied. To select the most rational mode of performing exercises in the process of motor skills development in boys, the first discriminant function can be used, with a focus on the most informative variables (Ivashchenko, Khudolii, Iermakov, Chernenko, \& Honcharenko, 2018).

Therefore, it is relevant to study the peculiarities of motor skills development in primary school children.

The study purpose was to determine the possibility of using pattern recognition methods to study the impact of physical exercises modes on teaching primary school children throwing a small ball at a vertical target.

\section{Materials and methods}

\section{Study participants}

The study participants were boys aged 7 years $(\mathrm{n}=48)$.

\section{Study organization}

The paper relied on analysis and generalization of data of scientific and methodological literature, general scientific methods of theoretical level, such as analogy, analysis, synthesis, abstraction, induction, as well as general scientific methods of empirical level: observation, testing, experiment.

The study used full $2^{3}$ type factorial experiment plans (see Table 1). The motor modes of teaching boys aged 7 throwing a ball at a target were studied. The purpose of the FFE was to optimize the modes of teaching and to determine the peculiarities of motor skill development in boys aged 7 based on the analysis of regression equations.

During a pedagogical experiment, the researchers studied the influence of the number of sets $\left(x_{1}\right)$, the number of repetitions per set $\left(x_{2}\right)$ and rest intervals $\left(x_{3}\right)$ on the level of proficiency in exercises performance of boys aged 7 .

When teaching throwing exercises, the study evaluated the level of proficiency during every class by the alternative method ("performed", "failed") and calculated the probability of exercise performance $(p=n / m$, where $n$ is the number of successful attempts, $m$ is the total number of attempts).

When teaching boys aged 7 , the study used the method of algorithmic instructions. The next exercise 
Table 1. Matrix for a $2^{3}$ type factorial experiment in studying the impact of different modes of repeating the exercise on the level of their performance proficiency

\begin{tabular}{lccc}
\hline \multirow{2}{*}{$\begin{array}{c}\text { Experimantal } \\
\text { Group }\end{array}$} & $\begin{array}{c}\boldsymbol{x}_{\mathbf{1}} \\
\text { number of } \\
\text { sets }\end{array}$ & $\begin{array}{c}\boldsymbol{x}_{\mathbf{2}} \\
\text { number of } \\
\text { repetitions per } \\
\text { set (times) }\end{array}$ & $\begin{array}{c}\boldsymbol{x}_{\mathbf{3}} \\
\text { rest } \\
\text { interval } \\
(\mathbf{s e c})\end{array}$ \\
\hline 1 & 6 & 1 & 60 \\
2 & 12 & 1 & 60 \\
3 & 6 & 3 & 60 \\
4 & 12 & 3 & 60 \\
5 & 6 & 1 & 180 \\
6 & 12 & 1 & 180 \\
7 & 6 & 3 & 180 \\
8 & 12 & 3 & 180 \\
\hline
\end{tabular}

was carried out after three successful attempts. Throwing a ball at a vertical target was taught.

\section{Statistical analysis}

The study used well-known methods of analyzing the results of a full $2^{\mathrm{k}}$ type factorial experiment (Khudolii \& Ivashchenko, 2014; Ivashchenko, 2016).

The study materials were processed using the IBM SPSS 20 statistical analysis program. In the process of discriminant analysis, the researchers created a prognostic model for group membership. This model builds a discriminant function (or, when there are more than two groups - a set of discriminant functions) in the form of a linear combination of predictor variables, which ensures the best division of groups. These functions are built according to a set of observations, for which their group membership is known. These functions can continue to be used for new observations with known values of predictor variables and unknown group membership.
For each canonical discriminant function, the study calculated: eigenvalue, dispersion percentage, canonical correlation, Wilks' Lambda, Chi-square.

To determine the impact of the suggested modes of physical exercises for boys aged 7, a discriminant analysis was conducted. The study analyzed the influence of the number of sets, the number of repetitions per set and the rest interval on the level of proficiency in the following movements: 1 . Throwing a ball against the floor; 2. Throwing a ball forward and up, feet shoulder width apart; 3 . Throwing a ball forward and up, left leg forward; 4 . Throwing a ball forward and up, left side to the throwing direction; 5 . Throwing a ball at a $3 \mathrm{~m}$ distant target.

The study protocol was approved by the Ethical Committee of the University. In addition, the children and their parents or legal guardians were fully informed about all the features of the study, and a signed informed-consent document was obtained from all the parents.

\section{Results}

The results of factorial experiment are shown in $\mathrm{Ta}$ bles 2 .

The analysis of regression equations showed that the level of proficiency in the first exercise "Throwing a ball against the floor" in boys aged 7 is influenced negatively by the number of repetitions per set $\left(x_{2}\right)$ and positevely - by the relationship between the number of sets and the number of repetitions per set $\left(x_{1} x_{2}\right)$ (see Table 2). The result in teaching depends on the number of repetitions per set $\left(x_{2}\right)$ by $72.25 \%$ and on the relationship between the number of sets and the number of repetitions per set $\left(x_{1} x_{2}\right)$ - by $16 \%$.

The level of proficiency in the second exercise "Throwing a ball forward and up, feet shoulder width apart" is influenced negatively by the number of repetitions $\left(x_{2}\right)$ and positevely - by the relationship between

Table 2. Regression dependence of the level of proficiency in throwing a small ball at a target on the number of sets $(\mathrm{x} 1)$, the number of repetitions per set (x2) and rest intervals (x 3$)$ in boys aged 7

\section{Number of Exercises}

1. Throwing a ball against the floor

2. Throwing a ball forward and up, feet shoulder width apart

3. Throwing a ball forward and up, left leg forward

4. Throwing a ball forward and up, left side to the throwing direction

Regression Equations for Coded Variables

$$
\begin{aligned}
& Y=0.76-0.085 x_{2}+0.04 x_{1} x_{2} \\
& Y=0.77-0.051 x_{2}+0.046 x_{1} x_{2} \\
& Y=0.8-0.044 x_{2}+0.049 x_{1} x_{2} \\
& Y=0.67+0.091 x_{1}+0.056 x_{2}-0.096 x_{1} x_{2}
\end{aligned}
$$


the number of sets and the number of repetitions per set $\left(x_{1} x_{2}\right)$. The result in teaching depends on the number of repetitions per set $\left(x_{2}\right)$ by $50.4 \%$ and on the relationship between the number of sets and the number of repetitions per set $\left(x_{1} x_{2}\right)$ - by $41.04 \%$

The level of proficiency in the third exercise "Throwing a ball forward and up, left leg forward" is influenced negatively by the number of repetitions $\left(x_{2}\right)$ and positevely - by the relationship between the number of sets and the number of repetitions per set $\left(x_{1} x_{2}\right)$. The result in teaching depends on the number of repetitions per set $\left(x_{2}\right)$ by $33.36 \%$ and on the relationship between the number of sets and the number of repetitions per set $\left(x_{1} x_{2}\right)$ - by $41.43 \%$.

There is a positive influence of the number of sets $\left(x_{1}\right)$, the number of repetitions per set $\left(x_{2}\right)$ and a negative influence of the relationship between the number of

Table 3. Canonical discriminant function. Eigenvalues. Boys aged 7

\begin{tabular}{ccccc}
\hline Function Eigenvalues & $\begin{array}{c}\text { \% Despersion } \\
\text { Explained }\end{array}$ & $\begin{array}{c}\text { Cumulative } \\
\text { \% }\end{array}$ & $\begin{array}{c}\text { Canonical } \\
\text { Correlation }\end{array}$ \\
\hline 1 & 1.662 & 57.6 & 57.6 & .790 \\
2 & .630 & 21.8 & 79.4 & .622 \\
3 & .503 & 17.4 & 96.8 & .579 \\
4 & .064 & 2.2 & 99.1 & .246 \\
5 & .027 & .9 & 100.0 & .162 \\
\hline
\end{tabular}

Table 4. Canonical discriminant function. Wilks' Lambda. Boys aged 7

\begin{tabular}{lcccc}
\hline $\begin{array}{c}\text { Verification } \\
\text { of Functions }\end{array}$ & Wilks' Lambda & Chi-Square & $\begin{array}{c}\text { Degrees of } \\
\text { Freedom }\end{array}$ & p \\
\hline from 1 to 5 & .140 & 79.548 & 35 & .000 \\
from 2 to 5 & .373 & 39.893 & 24 & .022 \\
from 3 to 5 & .609 & 20.108 & 15 & .168 \\
from 4 to 5 & .915 & 3.597 & 8 & .892 \\
5 & .974 & 1.076 & 3 & .783 \\
\hline
\end{tabular}

sets and the number of repetitions per set $\left(x_{1} x_{2}\right)$ on the level of proficiency in the fourth exercise "Throwing a ball forward and up, left side to the throwing direction". The result in teaching depends on the number of sets $\left(x_{1}\right)$ by $37.34 \%$, on the number of repetitions per set $\left(x_{2}\right)-$ by $14.18 \%$, and on the relationship between the number of sets and the number of repetitions per set $\left(x_{1} x_{2}\right)$ - by $41.54 \%$.

Therefore, the effectiveness of teaching boys aged 7 years "throwing a ball at a vertical target" is positively influenced by $6-12$ sets, 3 repetitions per set, rest interval of 60-180 seconds. The focus in choosing a teaching mode is on the number of repetitions per set.

To specify the impact of different modes of physical exercises on the level of proficiency, let us perform a discriminant analysis (see Tables 3-6).

The first canonical function explains $57.6 \%$, of the results variation, which indicates its high informative value $(r=0.790)$ (see Table 4$)$. The analysis of canonical functions proves a statistical significance of the first and second canonical functions $\left(\lambda_{1}=0.140 ; p_{1}=0.001\right.$; $\left.\lambda_{2}=0.373 ; p_{2}=0.022\right)$. The first and second functions have a high discriminative ability and meaning in the interpretation of the general population (Table 4).

The structure discriminant function coefficients, which are the coefficients of correlation between the variables and the function, indicate that the functions are closely connected with the level of proficiency in

Table 6. Functions in group centroids. Boys aged 7

\begin{tabular}{lccccc}
\hline \multirow{2}{*}{$\begin{array}{c}\text { Modes of } \\
\text { Training }\end{array}$} & \multicolumn{5}{c}{ Function } \\
\cline { 2 - 6 } 1.00 & $\mathbf{1}$ & $\mathbf{2}$ & $\mathbf{3}$ & $\mathbf{4}$ & $\mathbf{5}$ \\
2.00 & .164 & -1.516 & .727 & .215 & .056 \\
3.00 & -.229 & .180 & .522 & -.451 & .142 \\
4.00 & .026 & -.761 & -1.424 & -.129 & -.106 \\
5.00 & 2.167 & .410 & -.024 & -.117 & .019 \\
6.00 & -2.042 & .107 & -.199 & -.004 & .142 \\
7.00 & -.387 & .205 & .671 & -.054 & -.335 \\
8.00 & -.834 & .934 & -.127 & .266 & -.026 \\
\hline
\end{tabular}

Table 5. Structure canonical discriminant function coefficients. Boys aged 7

\begin{tabular}{|c|c|c|c|c|c|}
\hline \multirow[t]{2}{*}{ Content } & \multicolumn{5}{|c|}{ Function } \\
\hline & 1 & 2 & 3 & 4 & 5 \\
\hline 3. Throwing a ball forward and up, left leg forward & $.803^{*}$ & -.507 & .076 & -.038 & -.302 \\
\hline 2. Throwing a ball forward and up, feet shoulder width apart & .351 & $.591^{\star}$ & .100 & -.429 & .578 \\
\hline 5. Throwing a ball at a $3 \mathrm{~m}$ distant target & .196 & .223 & $.732^{\star}$ & .518 & -.328 \\
\hline $\begin{array}{l}\text { 4. Throwing a ball forward and up, left side to the throwing } \\
\text { direction }\end{array}$ & .414 & .511 & $-.536^{\star}$ & .146 & -.510 \\
\hline 1. Throwing a ball against the floor & .293 & -.114 & -.419 & .494 & $.694^{*}$ \\
\hline
\end{tabular}




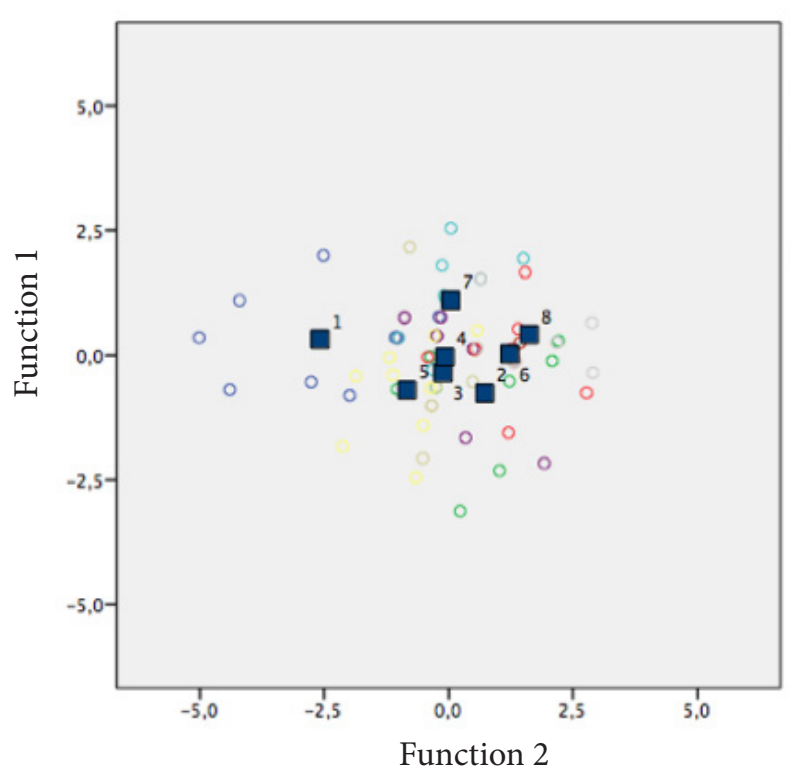

Fig. 1. Canonical discriminant functions. Graphic representation of classification results of the level of proficiency in exercises in boys aged 7: - - centroids for data groups after modes of exercises $1-8$

vaulting preliminary exercises. The level of proficiency in exercises depends on teaching modes, and the level of learning "Throwing a ball at a $3 \mathrm{~m}$ distant target" on the level of proficiency in preliminary exercises (Table 5).

The graphic material given in Fig. 1 shows the density of objects in each class and the distinct boundary between the classes, which indicates the possibility of choosing the mode of performing the exercise to successfully teach throwing a small ball at a vertical target (Table 6).

\section{Discussion}

The study assumed that a full factorial experiment and discriminant analysis would make it possible to determine the peculiarities of motor skills development in boys aged 7 . The obtained results show that the matrix for a full $2^{3}$ type factorial experiment given in Table 1 can be used to study the effectiveness of the learning process. A full factorial experiment method makes it possible to mathematically describe the process in some local area of the factorial space around the point with the coordinates of the $n$-dimensional space and to verify the regression model. Regression equations provide an opportunity to select the modes of performing for each exercise being studied.

The study makes an assumption on the possibility of using a discriminant function to evaluate the effectiveness of different modes of physical exercises when teaching a series of throwing exercises. The verification of canonical functions proves their statistical significance, and the discriminant function equation provides an opportunity to select the best option for obtaining a positive effect when teaching a series of exercises.

The results obtained:

- $\quad$ specify the conceptual approaches to planning the experiment in studying the learning process effectiveness and developing learning models in children (Khudolii, \& Ivashchenko, 2013; Ivashchenko, 2016; Ivashchenko, Khudolii, Iermakov, \& Harkusha, 2017);

- regression models given in Table 5 provide an opportunity to select the best option for teaching each exercise and supplement the conclusions on the effectiveness of using a full factorial experiment (FFE) in physical education and sports research (Khudolii, \& Iermakov, 2011; Khudolii, et al., 2016; Khudolii et al., 2015);

- supplement the information on the use of a discriminant function in the classification of schoolchildren by motor activity (Milić et al., 2011; Gert-Jan de Bruijn, \& Benjamin Gardner, 2011; Lulzim, 2013). As in the papers by Geoffrey D. Broadhead And Gabie E. Church (1982), Ivashchenko, Khudolii, \& Miroshnichenko, (2016), Ivashchenko, (2016), Khudolii et al. (2015), the study observed a high discriminative and predictive ability of the obtained functions in evaluating children's and adolescents' motor preparedness.

During the analysis, the study calculated canonical discriminant function coefficients (unstandardized) acting as factors of the given values of variables included in the discriminant functions. Based thereon, it is possible to classify the modes of exercises by the level of proficiency in physical exercises performance of boys aged 7 , which is of practical value.

In order to select the mode of performing throwing exercises, let us plug the level of proficiency in each exercise, which ensures a positive learning effect, into the discriminant function equation:

$$
\mathrm{Y}_{1}=-23.075+3.260 \mathrm{X}_{1}+6.485 \mathrm{X}_{2}+14.310 \mathrm{X}_{3}+
$$
$+2.467 \mathrm{X}_{4}+2.129 \mathrm{X}_{5}$ (function 1)

$\mathrm{Y}_{2}=-4.257-1.650 \mathrm{X}_{1}+7.641 \mathrm{X}_{2}-10.371 \mathrm{X}_{3}+5.859 \mathrm{X}_{4}$ $+4.645 \mathrm{X}_{5}$ (function 2)

where $\mathrm{Y}$ is the function result, $\mathrm{X}_{1}$ is the level of proficiency in exercise $1, X_{2}-$ the level of proficiency in exercise $2, \mathrm{X}_{3}$ - the level of proficiency in exercise 3, $\mathrm{X}_{4}$ - the level of proficiency in exercise $4, \mathrm{X}_{5}$ - the level of proficiency in exercise 5 .

Let us compare the obtained result $\left(\mathrm{Y}_{1}=-1.587\right.$; $\mathrm{Y}_{2}=0.336$ ) with the values of centroids for the first and second canonical functions (Table 4). The comparison shows that mode of training 4 ( 12 sets of 3 times per set, with a 60 -second rest interval) is the most favorable for teaching throwing to boys aged 7 . 
Consequently, the discriminant analysis allowed to answer the question as to the reliability of classification of physical exercises modes; as to how the level of proficiency in series of learning tasks influences the process of mastering the whole exercise; and what mode of performing exercises can be universal for teaching throwing exercises.

\section{Conclusions}

A full factorial experiment method makes it possible to mathematically describe the process in some local area of the factorial space and to verify the regression model. Regression equations provide an opportunity to select the modes of performing for each exercise being studied.

Discriminant analysis has made it possible to determine the modes of physical exercises in the process of motor skills development; to answer the question as to how significantly the modes of training differ by the effectiveness of motor skills development; what motor tasks most substantially influence the differentiation of classes; what class the object belongs to based on the values of discriminant variables.

To select the most rational mode of performing exercises in the process of motor skills development in boys aged 7 , the first and second discriminant functions can be used, with a focus on the most informative variables.

The prospect for further research is to study methodological approaches to pedagogical control in teaching physical exercises to primary-school-age children.

\section{Conflict of interest}

The authors state no conflict of interest.

\section{References}

Vaskov, Iu.V. (2016). Innovacijni pidkhodi do organizacii fizichnogo vikhovannia uchniv zagal'noosvitnikh navchal'nikh zakladiv [Innovative approaches to organization of comprehensive educational establishments' pupils physical education]. Teoriâ ta Metodika Fizičnogo Vihovannâ, 0(4), 5-12. https://doi. org/10.17309/tmfv.2016.4.1174 (in Ukrainian)

Arziutov, G., Iermakov, S., Bartik, P., Nosko, M., Cynarski, W.J. (2016). The use of didactic laws in the teaching of the physical elements involved in judo techniques. Ido Movement for Culture, 16(4), 21-30. https://doi. org/10.14589/ido.16.4.4

Khudolii, O.M., Ivashchenko, O.V., \& Chernenko, S.O. (2015). Simulation of junior shcoolchildren's training to acrobatic exercises and vaults. Pedagogics, psychology, medical-biological problems of physical training and sports, 19(7), 64-71. https://doi. org/10.15561/18189172.2015.0709
Krucevich, T. Yu., \& Bezverkhnia, H. V. (2010). Recreation in the physical culture of different population groups: teaching. manual. K. : Olimpiiska literatura, 248. (in Ukrainian)

Ivashchenko, O.V., Khudolii, O.M., Yermakova, T.S., Pilewska, Wiesława, Muszkieta, Radosław, \& Stankiewicz, Błazej (2015). Simulation as method of classification of 7-9th form boy pupils' motor fitness. Journal of Physical Education and Sport (JPES), 15(1), 142-147. https://doi.org/10.7752/jpes.2015.01023

Ivashchenko, O.V., Yermakova, T.S., Cieślicka, M., \& Sukowska, H. (2015). Discriminant analysis in classification of motor fitness of 9-11 forms' juniors. Journal of Physical Education and Sport (JPES), 15(2), 238-244. https://doi.org/10.7752/jpes.2015.02037

Khudolii, O.M., Iermakov, S.S., \& Prusik, K. (2015). Classification of motor fitness of 7-9 years old boys. Journal of Physical Education and Sport (JPES), 15(2), 245-253. https://doi.org/10.7752/jpes.2015.02038

Ekberg, J.-E. (2016). What knowledge appears as valid in the subject of Physical Education and Health? A study of the subject on three levels in year 9 in Sweden. Physical Education and Sport Pedagogy, 21(3), 249-267. https:// doi.org/10.1080/17408989.2014.946006

Lang, C., Feldmeth, A. K., Brand, S., Holsboer-Trachsler, E., Pühse, U., \& Gerber, M. (2017). Effects of a physical education-based coping training on adolescents' coping skills, stress perceptions and quality of sleep. Physical Education and Sport Pedagogy, 22(3), 213-230. https:// doi.org/10.1080/17408989.2016.1176130

Ivashchenko, O.V. (2016). Modelling of physical education students: Monograph. Kharkiv: OVS (in Ukrainian)

Ivashchenko, O.V. (2017). Classification of 11-13 yrs girls' motor fitness, considering level of physical exercises' mastering. Pedagogics, psychology, medical-biological problems of physical training and sports, 21(2), 65-70. https://doi.org/10.15561/18189172.2017.0203

Ivashchenko, O.V. (2017). Special aspects of motor abilities development in 6-10 years' age girls. Pedagogics, Psychology, Medical-Biological Problems Of Physical Training And Sports, 21(3), 105-110. https://doi. org/10.15561/18189172.2017.0302

Ivashchenko, O.V. (2017). Theoretical and methodological bases of modeling of learning process and development of motor abilities in children. Dokt. Diss. Chernigov, 40. (in Ukrainian)

Ivashchenko, O., \& Cieślicka, M. (2017). Features of evaluations of power loadsin boys 7 years old. Journal of Education, Health and Sport, 7(1), 175-183. https:// doi.org/10.5281/zenodo.249184

Ivashchenko, O. V. (2001). Methodic of gymnastic exercises training in school program. Teoriâ ta Metodika Fizičnogo Vihovannâ, O(1), 26-31. https://doi. org/10.17309/tmfv.2001.1.7 (in Ukrainian)

Miroshnychenko, D. T. (2007). Method of teaching acrobatic exercises of junior pupils. Teoriâ ta Metodika Fìzičnogo Vihovannâ, 0(12), 29-31. (in Ukrainian) 
Khudolii, O.M. (2008). Basics of the methodology of teaching gymnastics: A Manual. Kharkiv : OVS. (in Ukrainian)

Khudolii, O.M. (2008). General Fundamentals of Theory and Methodology of Physical Education: A Manual. Kharkiv : OVS. (in Ukrainian)

Nosko, M.O. (2001). Problems of training and improvement of human motor function. Pedagogics, Psychology, Medical-Biological Problems Of Physical Training And Sports, (5), 18-25. (in Ukrainian)

Nosko, M.O., Kryvenko, A.P., \& Manievych, O.R. (2001). Formation of motor skills in physical education and sports. Pedagogics, Psychology, Medical-Biological Problems Of Physical Training And Sports, (8), 7-9. (in Ukrainian)

Nosko, N.A., \& Sumak, E.H. (2000). Influence of different motor regimes on physical development and cardiovascular system of boys 8-10 years. Pedagogics, Psychology, Medical-Biological Problems Of Physical Training And Sports, (15), 24-26. (in Ukrainian)

Khudolii, O. M., \& Iermakov, S. S. (2011). Regularities of the learning process of young gymnasts. Teoriâ ta Metodika Fizičnogo Vihovannâ, 0(5), 3-18, 35-41. https://doi. org/10.17309/tmfv.2011.5.707 (in Ukrainian)

Khudolii, O.M., Ivashchenko, O.V., Iermakov, S.S., \& Rumba, O.G. (2016). Computer simulation of junior gymnasts' training process. Science of Gymnastics Journal, 8(3), 215-228.

Krucevich, T., Trachuk, S., Napadij, A. (2016). Planuvannia navchal'nogo procesu $\mathrm{z}$ fizichnoi kul'turi uchniv serednikh klasiv v zagal'noosvitnikh navchal'nikh zakladakh [Planning of physical culture training process for secondary comprehensive schools' pupils]. Teoriia i metodika fizichnogo vikhovannia i sportu, (1), 36-42. (in Ukrainian)

Darnis, F., \& Lafont, L. (2015) Cooperative learning and dyadic interactions: two modes of knowledge construction in socio-constructivist settings for teamsport teaching. Physical Education and Sport Pedagogy, 20(5), 459-473 https://doi.org/10.1080/17408989.2013 .803528

$\mathrm{Xu}, \mathrm{X} ., \mathrm{K}$ Ke F. (2014). From psychomotor to 'motorpsycho': Learning through gestures with body sensory technologies. Educational Technology Research and Development, 62(6), 711-741. https://doi.org/10.1007/ s11423-014-9351-8

Al-Ravashdeh Abdel Baset, Kozina, Z.L., Bazilyuk, T.A., \& Ilnickaya, A.S. (2015). Methodic of senior pupils' training to throwing movements on the bases of technology of complex impact on motor and intellectual development. Pedagogics, psychology, medical-biological problems of physical training and sports, 19(11), 3-10. https://doi. org/10.15561/18189172.2015.1101

Chatzipanteli, A., Digelidis, N., Karatzoglidis, C., \& Dean, R. (2016). A tactical-game approach and enhancement of metacognitive behaviour in elementary school students. Physical Education and Sport Pedagogy,
21(2),169-184. https://doi.org/10.1080/17408989.2014 .931366

Altunsoz, I.H., \& Goodway, J.D. (2016). Skiping to motor competence: the influence of project successful kinesthetic instruction for preschoolers on motor competence of disadvantaged preschoolers. Physical Education and Sport Pedagogy, 21(4), 366-385. https:// doi.org/10.1080/17408989.2015.1017453

Ivashchenko, O.V., \& Kapkan, O.O. (2015). Simulation of process of 14-15 years old girls' training of light athletic and gymnastic exercises. Pedagogics, psychology, medical-biological problems of physical training and sports, 19(8), 32-39. https://doi. org/10.15561/18189172.2015.0805

Kapkan, O.O. (2015). Features of 14-15 years' age boys' training to physical exercises. Pedagogics, psychology, medical-biological problems of physical training and sports, 19(9), 26-32. https://doi. org/10.15561/18189172.2015.0904

Khudolii, O. M., \& Ivashchenko, O. (2013). Information support learning and development of motor abilities of children and adolescents (for example, gymnastics). Teoriâ ta Metodika Fizičnogo Vihovannâ, O(4), 3-18. https://doi.org/10.17309/tmfv.2013.4.1031 (in Ukrainian)

Khudolii, O.M., \& Ivashchenko, O.V. (2014). Simulation of the learning process and development of motor abilities in children and adolescents: Monograph. Kharkiv : OVS, 320. (in Ukrainian)

Lopatiev, A., Ivashchenko, O., Khudolii, O., Pjanylo, Y., Chernenko, S. \& Yermakova T. (2017). Systemic approach and mathematical modeling in physical education and sports. Journal of Physical Education and Sport (JPES), 17(1), suplement, 146-155. https://doi. org/10.7752/jpes.2017.s1023

Vlasov, A., Demichkovskyy, A., Ivashchenko, O., Lopatiev, A., Pitin, M., Pjanylo, Y., \& Khudolii, O. (2016). Sistemnij pidkhid i matematichne modeliuvannia biologichnikh ta prirodnikh ob'iektiv i procesiv [Systemic approach and mathematical modeling of biological and natural objects and processes]. Fiziko-matematichne modeliuvannia ta informacijni tekhnologii, (23),17-28. (in Ukrainian)

Milić, M., Milavić, B., \& Grgantov, Z. (2011). Relations between sport involvement, selfesteem, sport motivation and types of computer usage in adolescents. In S. Simović (Ed.), Proceedings of 3rd International Scientific Congress "Anthropological Aspects of Sport, Physical Education and Recreation”. November 2011. Banja Luka: University of Banja Luka, Faculty of Physical Education and Sport.

Ivashchenko, O., Khudolii, O., Iermakov, S., Chernenko, S., \& Honcharenko, O. (2018). Full factorial experiment and discriminant analysis in determining peculiarities of motor skills development in boys aged 9. Journal of Physical Education and Sport, 18, 1958-1965. https:// doi.org/10.7752/jpes.2018.s4289

Gert-Jan de Bruijn and Benjamin Gardner (2011) Active Commuting and Habit Strength: An Interactive and 
Discriminant Analyses Approach. American Journal of Health Promotion, 25(3), e27-e36. https://doi. org/10.4278/ajhp.090521-QUAN-170

Lulzim, I., (2013) Discriminant analysis of morphologic and motor parameters of athlete and non athlete girl pupils of primary school on age 14 to 15 years. RIK, 40(2), 185-190. http://fsprm.mk/wp-content/ uploads/2013/08/Pages-from-Spisanie-RIKbr.-2-2012-9.pdf

Geoffrey D. Broadhead, \& Gabie E. Church. (1982). Discriminant Analysis of Gross and Fine Motor Proficiency Data. Perceptual and Motor Skills, 55(2), 547-552. https://doi.org/10.2466/pms.1982.55.2.547 Ivashchenko, O.V., Khudolii, O.M., \& Miroshnichenko, D.T. (2016). Structural model of the formation of motor function in girls of junior classes. Visnyk Chernihivskoho natsionalnoho pedahohichnoho universytetu. Seriia: Pedahohichni nauky. Fizychne vykhovannia ta sport, 139(1), 82-86. (in Ukrainian)

Ivashchenko, O. V. (2016). Methodic of pedagogic control of 16-17 years' age girls' motor fitness. Pedagogics, psychology, medical-biological problems of physical training and sports, 20(5), 26-32. https://doi. org/10.15561/18189172.2016.0504

Ivashchenko, O., Khudolii, O., Iermakov, S., \& Harkusha, S. (2017). Physical exercises' mastering level in classification of motor preparedness of 11-13 years old boys. Journal of Physical Education and Sport ${ }^{\circledR}$ (JPES), 17(3), 1031-1036. https://doi.org/10.7752/ jpes.2017.03158

\title{
РОЗПІЗНАННЯ ОБРАЗІВ: ХАРАКТЕРИСТИКА РЕЖИМІВ НАВЧАННЯ МЕТАННЮ МАЛОГО М'ЯЧА У ВЕРТИКАЛЬНУ ЦІЛЬ ХЛОПЧИКІВ 7 РОКІВ
}

\author{
Іващенко О.В. ${ }^{1}$, Носко М.О. ${ }^{2}$, Носко Ю.М. ${ }^{3}$, Черненко С.О. ${ }^{4}$ \\ ${ }^{1}$ Харківський національний педагогічний університет імені Г. С. Сковороди \\ ${ }^{2,3}$ Національний університет «Чернігівський колегіум» імені Тараса Шевченка \\ ${ }^{4}$ Донбаська державна машинобудівна академія \\ Реферат. Стаття: 9 с., 1 рис., 6 табл., 43 джерела
}

Мета роботи - визначити можливість використання методик розпізнання образів у вивченні впливу режимів виконання фізичних вправ на процес навчання метанню малого м'яча у вертикальну ціль школярів молодших класів.

Матеріали і методи. У дослідженні прийняли участь хлопчики 7 років $(\mathrm{n}=48)$. У роботі використані аналіз й узагальнення даних наукової та методичної літератури, загально-наукові методи теоретичного рівня, такі, як аналогія, аналіз, синтез, абстрагування, індукція, а також загально-наукові методи емпіричного рівня: спостереження, тестування, експеримент.

Результати. На ефективність процесу навчання хлопчиків 7 років «кидку м'яча у вертикальну ціль» позитивно впливає 6-12 підходів, кількість повторень у підході 3 рази, інтервал відпочинку триває 60-180 с. Акцент у виборі режиму навчання робиться на кількості повторень у підході.

Висновки. Метод повного факторного експерименту дозволяє отримати математичний опис про- цесу в деякій локальній області факторного простору та провести верифікацію регресійної моделі. Рівняння регресії дають можливість підбору режимів виконання для кожної вправи, яка вивчається. Дискримінантний аналіз дозволив визначити режими виконання фізичних вправ у процесі формування рухових навичок; дати відповідь на питання наскільки достовірно різняться режими роботи за результативністю формування рухових навичок; які рухові завдання найбільш суттєво впливають на розрізнення класів; до якого класу належить об'єкт на основі значень дискримінантних змінних. Для вибору найбільш раціонального режиму виконання вправ у процесі формування рухових навичок у хлопчиків 7 років може бути використана перша і друга дискримінантні функції з акцентом на найбільш інформативні змінні.

Ключові слова: навчання, хлопці 7 років, факторний експеримент, дискримінантний аналіз. 


\title{
РАСПОЗНАВАНИЕ ОБРАЗОВ: ХАРАКТЕРИСТИКА РЕЖИМОВ ОБУЧЕНИЯ МЕТАНИЮ МАЛОГО МЯЧА В ВЕРТИКАЛЬНУЮ ЦЕЛЬ МАЛЬЧИКОВ 7 ЛЕТ
}

\author{
Иващенко О.В. ${ }^{1}$, Носко Н.А. ${ }^{2}$, Носко Ю.Н. ${ }^{3}$, Черненко С.А. ${ }^{4}$ \\ ${ }^{1}$ Харьковский национальный педагогический университет имени Г. С. Сковороды \\ ${ }^{2,3}$ Национальный университет «Черниговский коллегиум» имени Тараса Шевченко \\ ${ }^{4}$ Донбаская государственная машиностроительная академия
}

Реферат. Статья: 9 с., 1 рис., 6 табл., 43 источника.

Цель работы - определить возможность использования методик распознавания образов в изучении влияния режимов выполнения физических упражнений на процесс обучения метанию малого мяча в вертикальную цель школьников младших классов.

Материалы и методы. В исследовании приняли участие мальчики 7 лет $(\mathrm{n}=48)$. В работе использованы анализ и обобщение данных научной и методической литературы, научные методы теоретического уровня, такие, как аналогия, анализ, синтез, абстрагирование, индукция, а также научные методы эмпирического уровня: наблюдение, тестирование, эксперимент.

Результаты. На эффективность процесса обучения мальчиков 7 лет «метанию мяча в вертикальную цель» положительно влияет 6-12 подходов, количество повторений в подходе 3 раза, интервал отдыха длится 60-180 с. Акцент в выборе режима обучения делается на количестве повторений в подходе.

Выводы. Метод полного факторного эксперимента позволяет получить математическое описа- ние процесса в некоторой локальной области факторного пространства и провести верификацию регрессионной модели. Уравнения регрессии дают возможность подбора режимов выполнения для каждого упражнения, которое изучается. Дискриминантный анализ позволил определить режимы выполнения физических упражнений в процессе формирования двигательных навыков; дать ответ на вопрос насколько достоверно отличаются режимы работы по результативности формирования двигательных навыков; какие двигательные задачи наиболее существенно влияют на различия классов, к какому классу принадлежит объект на основе значений дискриминантных переменных. Для выбора наиболее рационального режима выполнения упражнений в процессе формирования двигательных навыков у мальчиков 7 лет может быть использована первая и вторая дискриминантные функции с акцентом на наиболее информативные переменные.

Ключевые слова: обучение, мальчики 7 лет, факторный эксперимент, дискриминантный анализ.

\section{Information about the authors:}

Ivashchenko O.V.: olga@tmfv.com.ua; https://orcid.org/0000-0002-2708-5636; Department of Theory and Methodology of Physical Education, H. S. Skovoroda Kharkiv National Pedagogical University,

Alchevskikh St, 29, Kharkiv, 61002, Ukraine.

Nosko M.O.: chnpu@chnpu.edu.ua; https://orcid.org/0000-0001-9903-9164; Department of Pedagogy, Psychology and Methodology of Physical Education, Taras Shevchenko National University of "Chernihiv Collegium", Hetman Polubotka St, 70, Chernihiv, Chernigov region, 14000, Ukraine.

Nosko Yu.M.: chnpu@chnpu.edu.ua; http://orcid.org/0000-0003-1077-8206; Taras Shevchenko National University of "Chernihiv Collegium", Hetman Polubotka St, 70, Chernihiv, Chernigov region, 14000, Ukraine.

Chernenko S.O.: chernenko.sergey65@ukr.net; https://orcid.org/0000-0001-9375-4220; Department of Physical Education, Donbas State Engineering Academy, Academic St, 72, Kramatorsk, 84313, Ukraine.

Cite this article as: Ivashchenko, O.V., Nosko, M.O., Nosko, Yu.M., \& Chernenko, S.O. (2019). Pattern Recognition: Description of Modes of Teaching Boys Aged 7 Throwing a Small Ball at a Vertical Target. Teoriâ ta Metodika Fizičnogo Vihovannâ, 19(3), 130-1138. https://doi.org/10.17309/tmfv.2019.3.04

Received: 10.08.2019. Accepted: 20.09.2019. Published: 25.09.2019

This work is licensed under a Creative Commons Attribution 4.0 International License (http://creativecommons.org/ licenses/by/4.0). 